\title{
Evidence-based medicine: quality and comparability of clinical trials investigating the efficacy of prostaglandin $F_{2 \alpha}$ for the treatment of bovine endometritis
}

\author{
Peggy Haimerl, Sebastian Arlt and Wolfgang Heuwieser* \\ Clinic for Animal Reproduction, Faculty of Veterinary Medicine, Freie Universität Berlin, Koenigsweg 65, 14163 Berlin, Germany
}

Received 23 November 2011; accepted for publication 14 February 2012; first published online 17 April 2012

\begin{abstract}
The objective of this study was to evaluate the quality and comparability of published literature, and to summarize the effect of prostaglandin $\mathrm{F}_{2 \alpha}\left(\mathrm{PGF}_{2 \alpha}\right)$ for the treatment of endometritis. It has been postulated that there is a dearth of high-level evidence-based research results in veterinary medicine. Also, there is a marked variation in the quality of studies in veterinary and animal science. Postpartum uterine infections occur commonly in dairy cattle and are reported to have a negative impact on reproductive performance. A comprehensive literature search was conducted utilizing online databases revealing a total of 2723 references. After applying specific exclusion criteria, a total of 68 trials were eligible for further analysis. These articles were evaluated utilizing specific parameters listed in an evaluation form such as randomization and the involvement of control groups. The analysis revealed that more than half of the trials $(51.5 \%)$ were at least 20 years old. Furthermore, we found that about one third (36.8\%) of all trials were controlled and randomized, while 3 of those $(4 \cdot 4 \%)$ were also blinded. Of those trials which calculated a calving-to-conception interval $(n=30)$, $50 \%$ of the authors claimed an improvement, which was statistically significant in $23.3 \%$ of the cases. We conclude that there is a wide discrepancy between research results investigating the efficacy of $\mathrm{PGF}_{2 \alpha}$.
\end{abstract}

Keywords: Endometritis, treatment, evidence, dairy cattle.

The decision-making process of practising veterinarians as well as farm personnel and animal scientists should be based on objective information (Holmes \& Cockcroft, 2004). Therefore the implementation of evidence-based medicine becomes increasingly important. Sackett et al. (1996) defined evidence-based medicine as the conscientious, explicit and judicious use of the best external evidence currently available, for the purpose of making decisions concerning the medical care of individual patients. The term 'evidence' demonstrates the degree of certainty with which the results of a study reliably represent reality (Arlt \& Heuwieser, 2005).

However, Holmes \& Cockcroft (2004) have postulated that there is a dearth of methodologically performed, rigorous, large-scale clinical studies in veterinary medicine resulting in a lack of research results of high evidence. This hypothesis has been supported by several authors (Mair \& Cohen, 2003; Arlt et al. 2010) who demonstrated that in veterinary medicine the increase of knowledge is mainly

*For correspondence; e-mail: w.heuwieser@fu-berlin.de based on reviewing field reports rather than randomized, controlled clinical studies. Nevertheless, researchers seem to have become increasingly aware of this problem. Not only did several authors develop some kind of guidelines concerning the question of how to conduct high-quality studies or meta-analyses (e.g. Lean et al. 2009). Also, many very well-conducted studies eligible for performing metaanalyses have been published during recent years (Rabiee et al. 2005; Lean et al. 2006). Nevertheless, randomized, controlled, double-blinded studies are the gold standard with regard to the evaluation of a given treatment (Kastelic, 2006). The quality of a certain study depends on its design, its clinical relevance, the analysis of the study results, and the quality and comprehensiveness of the reporting (Arlt \& Heuwieser, 2005). Four stages of evidence have been suggested to categorize studies with respect to their quality (Bassler \& Antes, 2000). Stage I represents the highest level of evidence and refers to meta-analyses of randomized, controlled studies or evidence gained from at least one randomized, controlled study. Well-designed, controlled studies without randomization and well-designed, quasi-experimental studies generate evidence of stage II. 
Table 1. Research articles $(n=68)$ studying the efficacy of $\mathrm{PGF}_{2 \alpha}$ treatment of chronically endometritic cows chosen for evaluation

\begin{tabular}{|c|c|c|c|}
\hline Author & $\begin{array}{l}\text { Year of } \\
\text { publication }\end{array}$ & Title & Journal/Source \\
\hline Anderson, D.B. & 1985 & Chronic endometritis - a field study & $\begin{array}{l}\text { Proceedings for 1983-84 of British Cattle } \\
\text { Veterinary Association }\end{array}$ \\
\hline Anderson, D.B. & 1988 & $\begin{array}{l}\text { The role of prostaglandin therapy in the early post-partum } \\
\text { cow }\end{array}$ & $\begin{array}{l}\text { Proceedings for } 1986-87 \text { British Cattle } \\
\text { Veterinary Association }\end{array}$ \\
\hline Baars, J.C. & 1980 & $\begin{array}{l}\text { Prostaglandin (Prosolvin) treatment of uterine disorders in } \\
\text { the dairy cow }\end{array}$ & $\begin{array}{l}\text { Proceeding of XI International Congress } \\
\text { on Diseases of Cattle }\end{array}$ \\
\hline Bach, S. & 1985 & Prostaglandin F2 alpha (Enzaprost) for treating infertile cows & $\begin{array}{l}\text { Archiv für Experimentelle } \\
\text { Veterinärmedizin }\end{array}$ \\
\hline Barvi, S.A. & 1994 & $\begin{array}{l}\text { Comparative efficacy of cloprostenol and estradiol for the } \\
\text { treatment of endometritis in crossbred dairy cows }\end{array}$ & Pakistan Veterinary Journal \\
\hline Bentele, W. & 1980 & Efficacy of tiaprost for the treatment of bovine endometritis & Tierärztliche Umschau \\
\hline Bentele, W. & 1980 & $\begin{array}{l}\text { Treatment of pyometra and lochiometra in cattle with the } \\
\text { prostaglandin F2 analogue tiaprost }\end{array}$ & Tierärztliche Umschau \\
\hline Böhme, H. & 1986 & Effectiveness of various treatments in the late puerperium & Tierhygiene-Information \\
\hline Bonnett, BN & 1988 & $\begin{array}{l}\text { Prostaglandin therapy and its relationship to histology, } \\
\text { culture results and subsequent reproductive performance } \\
\text { in dairy cows biopsied at } 26 \text { and } 40 \mathrm{~d} \text { post partum }\end{array}$ & $\begin{array}{l}\text { Proceedings of } 11 \text { th International } \\
\text { Congress on Animal Reproduction and } \\
\text { Artificial Insemination, }\end{array}$ \\
\hline Bruns, G.U. & 1997 & $\begin{array}{l}\text { Comparative study of the treatment of bovine endometritis } \\
\text { with the prostaglandin analogue cloprostenol or a } \\
\text { combination of metacresolsulfonic acid and formaldehyde } \\
\text { ('Lotagen') }\end{array}$ & $\begin{array}{l}\text { Thesis, Tierarztliche Hochschule, } \\
\text { Hannover, Germany }\end{array}$ \\
\hline Callahan, C.J. & 1993 & $\begin{array}{l}\text { Treatment of post-partum metritis in dairy cows caused by } \\
\text { Actinomyces pyogenes }\end{array}$ & Bovine Practitioner \\
\hline Chauhan, F. S. & 1983 & $\begin{array}{l}\text { Treatment of chronic endometritis with prostaglandin } \mathrm{F}_{2 \alpha} \\
\text { and antibiotic in cows and buffaloes }\end{array}$ & Indian Veterinary Journal \\
\hline Copeland, D.D. & 1978 & $\begin{array}{l}\text { Therapeutic and feedlot abortion application of } \\
\text { prostaglandins }\end{array}$ & Bovine Practitioner \\
\hline Coulson, A. & 1978 & Treatment of metritis in cattle with prostaglandin $\mathrm{F}_{2 \alpha}$ & Veterinary Record \\
\hline Drillich, $M$. & 2002 & $\begin{array}{l}\text { Effects of the intensity of a post-partum examination on } \\
\text { reproductive performance in high yielding dairy cows }\end{array}$ & Deutsche Tierärztliche Wochenschrift \\
\hline Drillich, $M$. & 2005 & $\begin{array}{l}\text { Treatment of chronic endometritis in dairy cows with } \\
\text { cephapirin, tiaprost or a combination of both }\end{array}$ & Tierärztliche Praxis \\
\hline Drillich, $M$. & 2005 & $\begin{array}{l}\text { Treatment of chronic endometritis in dairy cows with an } \\
\text { intrauterine application of enzymes: a field trial }\end{array}$ & Theriogenology \\
\hline Duncanson, G.R. & 1980 & $\begin{array}{l}\text { A four year study on a hundred and twenty cow dairy unit } \\
\text { with a high rate of retained placenta and subsequent } \\
\text { endometritis }\end{array}$ & $\begin{array}{l}\text { Proceeding of XI. International Congress } \\
\text { On Diseases of Cattle }\end{array}$ \\
\hline Etherington, W.G. & 1985 & $\begin{array}{l}\text { Interrelationships between post-partum events, hormonal } \\
\text { therapy, reproductive abnormalities and reproductive } \\
\text { performance in dairy cows: a path analysis }\end{array}$ & $\begin{array}{l}\text { Canadian Journal of Comparative } \\
\text { Medicine }\end{array}$ \\
\hline Falkenberg, U. & 2005 & $\begin{array}{l}\text { Influence of time of initiation of a prostaglandin } \mathrm{F}_{2 \alpha} \text { protocol } \\
\text { in dairy cows with puerperal endometritis }\end{array}$ & Deutsche Tierärztliche Wochenschrift \\
\hline Feldmann, M. & 2005 & $\begin{array}{l}\text { [Treatment of chronic bovine endometritis and factors for } \\
\text { treatment success] }\end{array}$ & Deutsche Tierärztliche Wochenschrift \\
\hline Fivaz, B.H. & 1978 & Bovine post-partum metritis and the reconception period & Rhodesian Veterinary Journal \\
\hline Guay, P. & 1980 & $\begin{array}{l}\text { Metritis following parturition: serum progesterone and } 17 \\
\text { beta-oestradiol levels. The significance of the corpus } \\
\text { luteum and the advisability of using a luteolytic agent as a } \\
\text { treatment }\end{array}$ & Canadian Veterinary Journal \\
\hline Günzler, von O. & 1979 & $\begin{array}{l}\text { Treatment of pyometra in cows with Estrumate } \\
\text { (cloprostenol) }\end{array}$ & Tierärztliche Umschau \\
\hline Heuwieser, W. & 2000 & $\begin{array}{l}\text { Effect of three programmes for the treatment of endometritis } \\
\text { on the reproductive performance of a dairy herd }\end{array}$ & Veterinary Record \\
\hline Hirsbrunner, G. & 2006 & $\begin{array}{l}\text { Effects of a single administration of prostaglandin } \mathrm{F}_{2 \alpha,} \text { or a } \\
\text { combination of prostaglandin } \mathrm{F}_{2 \alpha} \text { and prostaglandin } \mathrm{E} 2 \text {, or } \\
\text { placebo on fertility variables in dairy cows } 3-5 \text { weeks post } \\
\text { partum, a randomized, double-blind clinical trial }\end{array}$ & Reproductive Biology and Endocrinology \\
\hline
\end{tabular}


Table 1. (Cont.)

\begin{tabular}{|c|c|c|c|}
\hline Author & $\begin{array}{l}\text { Year of } \\
\text { publication }\end{array}$ & Title & Journal/Source \\
\hline Huggenberger, G. & 1982 & $\begin{array}{l}\text { Comparison of prostaglandin analogues (cloprostenol and } \\
\text { tiaprost) with Lugol's iodine solution for treating chronic } \\
\text { endometritis in cows }\end{array}$ & $\begin{array}{l}\text { Thesis, Ludwig-Maximilians-Universitat } \\
\text { München, Germany }\end{array}$ \\
\hline Humke, R. & $\begin{array}{l}1982 \\
(\text { Exp. 1) }\end{array}$ & $\begin{array}{l}\text { The treatment of genital catarrhs of cattle with a } \\
\text { prostaglandin analog and antibiotics } 0 \cdot 1 \text {. Individual } \\
\text { application of the drugs }\end{array}$ & Tierärztliche Umschau \\
\hline Humke, R. & $\begin{array}{l}1982 \\
(\text { Exp. 2) }\end{array}$ & $\begin{array}{l}\text { The treatment of genital catarrhs of cattle with a } \\
\text { prostaglandin analog and antibiotics } 0 \cdot 1 \text {. Individual } \\
\text { application of the drugs }\end{array}$ & Tierärztliche Umschau \\
\hline Hüntelmann, C. & 2005 & $\begin{array}{l}\text { Investigation on the influence of time of post-partum } \\
\text { examination and the initiation of a } \mathrm{PGF}_{2 \alpha} \text { treatment of } \\
\text { chronic endometritis in dairy cows }\end{array}$ & $\begin{array}{l}\text { Thesis, Freie Universitat Berlin, Berlin, } \\
\text { Germany }\end{array}$ \\
\hline Jackson, P.S. & $\begin{array}{l}1977 \\
(\text { Exp. 1) }\end{array}$ & $\begin{array}{l}\text { Treatment of chronic post-partum endometritis in cattle with } \\
\text { cloprostenol }\end{array}$ & Veterinary Record \\
\hline Jackson, P.S. & $\begin{array}{l}1977 \\
(\text { Exp. 2) }\end{array}$ & $\begin{array}{l}\text { Treatment of chronic post-partum endometritis in cattle with } \\
\text { cloprostenol }\end{array}$ & Veterinary Record \\
\hline Jacob, T.C. & 1993 & Prostaglandin therapy for bovine endometritis & Journal of Veterinary and Animal Sciences \\
\hline Jacob, T.C. & 1995 & $\begin{array}{l}\text { Oestrus induction using } \text { PGF }_{2 \alpha} \text { in crossbred cows with } \\
\text { post-partum clinical endometritis }\end{array}$ & Indian Journal of Animal Reproduction \\
\hline Janowski, T. & 2001 & $\begin{array}{l}\text { Combined } \mathrm{GnRH} \text { and } \mathrm{PGF}_{2 \alpha} \text { application in cows with } \\
\text { endometritis puerperalis treated with antibiotics }\end{array}$ & Reproduction in Domestic Animals \\
\hline Kaufmann, T.B. & 2010 & $\begin{array}{l}\text { Systemic antibiotic treatment of clinical endometritis in } \\
\text { dairy cows with ceftiofur or two doses of cloprostenol in a } \\
14-d \text { interval }\end{array}$ & Animal Reproduction Science \\
\hline Knutti, B. & 2000 & $\begin{array}{l}\text { Reproductive efficiency of cows with endometritis after } \\
\text { treatment with intrauterine infusions or prostaglandin } \\
\text { injections, or no treatment }\end{array}$ & Journal of Veterinary Medicine \\
\hline Laven, R.A. & 2003 & $\begin{array}{l}\text { Understanding the dynamics of bovine endometritis: } \\
\text { comparison of the response to injectable luprostiol and } \\
\text { topical cephapirin }\end{array}$ & Cattle Practice \\
\hline Le Blanc, S.J. & 2003 & $\begin{array}{l}\text { Field study of the diagnosis and treatment of clinical } \\
\text { endometritis in dairy cattle }\end{array}$ & Journal of Dairy Science \\
\hline Leidl, von W. & 1983 & Treatment of endometritis in cattle & Praktischer Tierarzt \\
\hline Lusky, K & 1984 & $\begin{array}{l}\text { Use of the cloprostenol preparation 'Oestrophan' for } \\
\text { treating reproductive disorders in cattle }\end{array}$ & Monatshefte für Veterinärmedizin \\
\hline Mansfeld, R. & 1999 & $\begin{array}{l}\text { Two different programs to improve reproductive efficiency } \\
\text { in dairy herds with special regard to the treatment of } \\
\text { endometritis }\end{array}$ & Reproduction in Domestic Animals \\
\hline Markusfels, O. & 1984 & $\begin{array}{l}\text { The influence of post parturient metritis, corpus luteum } \\
\text { enucleation and cloprostenol on conception rates in dairy } \\
\text { cows }\end{array}$ & Refuah Veterinarith \\
\hline Mejia, M.E. & $\begin{array}{l}2004 \\
(\text { Exp. 1) }\end{array}$ & $\begin{array}{l}\text { Endometritis treatment with a } \mathrm{PGF}_{2 \alpha} \text { analog does not } \\
\text { improve reproductive performance in a large dairy herd in } \\
\text { Argentina }\end{array}$ & Theriogenology \\
\hline Mejia, M.E. & $\begin{array}{l}2004 \\
(\text { Exp. 2) }\end{array}$ & $\begin{array}{l}\text { Endometritis treatment with a } \mathrm{PGF}_{2 \alpha} \text { analog does not } \\
\text { improve reproductive performance in a large dairy herd in } \\
\text { Argentina }\end{array}$ & Theriogenology \\
\hline Michiel, G. & 1995 & $\begin{array}{l}\text { Efficacy of three injectable solutions of the prostaglandin } \\
\text { analogue luprostiol for treating recently calved cows and } \\
\text { cases of anoestrus or endometritis }\end{array}$ & $\begin{array}{l}\text { Thesis, Justus-Liebig-Universitat, Giessen, } \\
\text { Germany }\end{array}$ \\
\hline Murray, R.D. & 1990 & $\begin{array}{l}\text { Bovine endometritis: comparative efficacy of alfaprostol } \\
\text { and intrauterine therapies, and other factors influencing } \\
\text { clinical success }\end{array}$ & Veterinary Record \\
\hline Nakao, T. & $\begin{array}{l}1997 \\
\text { (Exp. 3) }\end{array}$ & $\begin{array}{l}\text { Post-partum plasma PGF metabolite profile in cows with } \\
\text { dystocia and/or retained placenta, and effect of } \\
\text { fenprostalene on uterine involution and reproductive } \\
\text { performance }\end{array}$ & Journal of Veterinary Medical Science \\
\hline
\end{tabular}


Table 1. (Cont.)

\begin{tabular}{|c|c|c|}
\hline Author & $\begin{array}{l}\text { Year of } \\
\text { publication }\end{array}$ & Title \\
\hline Narayana, K. & 1986 & $\begin{array}{l}\text { The clinical efficacy of low-dose cloprostenol, a } \\
\text { prostaglandin } \mathrm{F}_{2 \alpha} \text { analogue, in infertile conditions in cattle } \\
\text { and buffaloes }\end{array}$ \\
\hline Ohtani, S. & 1997 & $\begin{array}{l}\text { Effect of intrauterine infusion of polyvinyl-pyrrolidone } \\
\text { iodine and intramuscular injection of prostaglandin } \mathrm{F}_{2 \alpha} \text { on } \\
\text { reproductive performance in cows }\end{array}$ \\
\hline Otel, V. & 1985 & Practical results in regulating the puerperal period of cows \\
\hline Pepper, R.T. & 1985 & Survey of the treatment of bovine endometritis \\
\hline Pepper, R.T. & $\begin{array}{l}1987 \\
(\text { Exp. 1) }\end{array}$ & $\begin{array}{l}\text { Preliminary results of treatment and endocrinology of } \\
\text { chronic endometritis in the dairy cow }\end{array}$ \\
\hline Piccinelli, F. & 1989 & Treatment of uterine diseases in cows with prostaglandins \\
\hline Rao, Y. & 2001 & $\begin{array}{l}\text { Evaluation of } \mathrm{PGF}_{2 \alpha} \text { analog treatment with and without } \\
\text { antibacterials in endometritis in crossbred cattle }\end{array}$ \\
\hline Roy, G.P. & 1990 & $\begin{array}{l}\text { Trials of Dinofertin in different types of reproductive } \\
\text { disorders }\end{array}$ \\
\hline Sarkar, P. & 2006 & $\begin{array}{l}\text { Effect of administration of garlic extract and } \mathrm{PGF}_{2 \alpha} \text { on } \\
\text { hormonal changes and recovery in endometritis cows }\end{array}$ \\
\hline Sheldon, I.M. & 1997 & Comparison of three treatments for bovine endometritis \\
\hline Sood, P. & 2003 & $\begin{array}{l}\text { Impact of uterine microbial panorama on the therapeutic } \\
\text { efficacy of single injection of } \mathrm{PGF}_{2 \alpha} \text { in cows with clinical } \\
\text { endometritis }\end{array}$ \\
\hline Sprowson, G.W. & 1981 & $\begin{array}{l}\text { Therapeutic use of prostaglandin } \mathrm{F}_{2 \alpha} \text { during the post-partum } \\
\text { period in dairy cows [cloprostenol] }\end{array}$ \\
\hline Steffan, J. & 1984 & $\begin{array}{l}\text { Treatment of metritis with antibiotics or prostaglandin } \mathrm{F}_{2 \alpha} \\
\text { and influence of ovarian cyclicity in dairy cows }\end{array}$ \\
\hline Tenhagen, B.A. & 2003 & $\begin{array}{l}\text { Influence of stage of lactation and milk production on } \\
\text { conception rates after timed artificial insemination } \\
\text { following Ovsynch }\end{array}$ \\
\hline Thiel, K.C. & 1998 & $\begin{array}{l}\text { Treatment of bovine endometritis, of differing degrees of } \\
\text { severity, with cloprostenol or povidone-iodine solution, } \\
\text { with reference to plasma progesterone and the uterine } \\
\text { microflora at the time of treatment }\end{array}$ \\
\hline Tischer, $M$. & 1998 & $\begin{array}{l}\text { Treatment of chronic endometritis among cows of a dairy } \\
\text { herd: combination of intrauterine antiseptic therapy with a } \\
\text { prostaglandin analogue (tiaprost) }\end{array}$ \\
\hline Tsousis, G. & 2005 & $\begin{array}{l}\text { Strategien der Endometritisbehandlung und Auswirkung auf } \\
\text { die klinische Heilung und die Fruchtbarkeit von } \\
\text { Milchkühen im Rahmen der Integrierten Tierärztlichen } \\
\text { Bestandsbetreuung }\end{array}$ \\
\hline Wenkoff, M.S. & 1978 & $\begin{array}{l}\text { Therapeutic evaluation of the use of prostaglandin analog } \\
\text { ICl80996 in cattle }\end{array}$ \\
\hline $\begin{array}{l}\text { Wonchee } \\
\text { Solorzano, Z. }\end{array}$ & 2002 & $\begin{array}{l}\text { Evaluation of different treatments used in the early post } \\
\text { partum in dairy cows with metritis }\end{array}$ \\
\hline Zuber, H. & 1980 & $\begin{array}{l}\text { Practical experiences with the prostaglandin analogue } \\
\text { Estrumate for the treatment of endometritis in cattle }\end{array}$ \\
\hline
\end{tabular}

Journal/Source

Indian Veterinary Journal

Reproduction in Domestic Animals

Tierärztliche Umschau

Proceedings for 1983-84 British Cattle

Veterinary Association

Veterinary Record

Praktischer Tierarzt

Indian Veterinary Journal

Indian Veterinary Journal

Asian-Australasian Journal of Animal

Sciences

Cattle Practice

Indian Journal of Animal Sciences

Zimbabwe Veterinary Journal

American Journal of Veterinary Research

Theriogenology

Thesis, Tierarztliche Hochschule,

Hannover., Germany

Thesis, Freie Universitat, Berlin, Germany

Thesis, Tierärztliche Hochschule

Hannover, Germany

Canadian Veterinary Journal

Tecnica Pecuaria en Mexico

Deutsche Tierärztliche Wochenschrift
Evidence being categorized as stage III is obtained through well-designed, descriptive studies that are not experimental. Finally, the lowest stage of evidence (stage IV) covers opinions of experts, results presented at scientific meetings as well as clinical experience of accredited authorities. In order to improve the quality of publications, scientists developed checklists containing important aspects for conducting trials. For instance, the CONSORT and the PRISMA statements aim to improve the reporting of randomized clinical trials, as well as systematic reviews and meta-analyses. The REFLECT statement is a modification of the CONSORT statement for veterinary science as livestock and food safety. Besides the lack of high-evidence studies, there is a marked variation in the quality of studies in veterinary science, resulting in insufficient comparability of the various trials (Cockcroft \& Holmes, 2003).

Clinical endometritis in cattle is defined as the presence of a purulent ( $>50 \%$ pus) uterine discharge detectable in the 
Table 2. Relevant criteria of 68 trials studying the efficacy of $\mathrm{PGF}_{2 \alpha}$ treatment of chronically endometritic cows

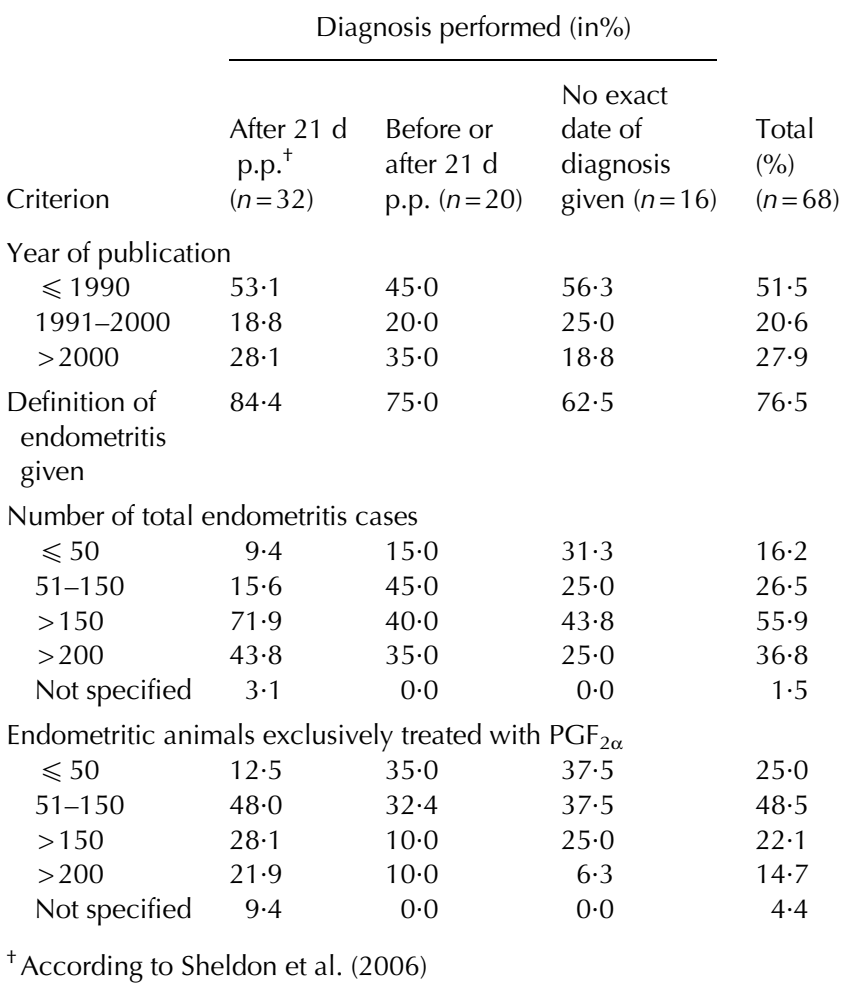

vagina $21 \mathrm{~d}$ or more post partum, or mucopurulent (approximately 50\% pus, 50\% mucus) discharge detectable in the vagina after $26 \mathrm{~d}$ post partum, (Sheldon et al. 2006). Most recently, following a study conducted by Runciman et al. (2008) which aimed to evaluate the role of vaginoscopy in predicting a reduction in reproductive performance parameters associated with a positive discharge detected by vaginoscopy, cytological endometritis diagnosed with a cytobrush and purulent vaginal discharges diagnosed by Metricheck device have been described as distinct manifestations of uterine inflammation (Dubuc et al. 2010b). The prevalence of post-partum uterine infections (up to $57 \cdot 7 \%$ ) (Sheldon, 2009) and the resulting opportunity costs (decreased fertility, increased culling) underline the importance of this disease (Plaizier et al. 1998; LeBlanc et al. 2002a; LeBlanc, 2008).

There is a wealth of information on the treatment of endometritis and this subject has been reviewed extensively by several authors (Gilbert \& Schwark, 1992; Olson, 1996; Azawi, 2008). However, the treatment of endometritis is still an issue of considerable controversy (Arlt et al. 2009; Dubuc et al. 2011). This may be due to the wide variety of therapies available for endometritis, including systemic or local antibiotics, prostaglandin $\mathrm{F}_{2 \alpha}\left(\mathrm{PGF}_{2 \alpha}\right)$ and oestradiol.

Numerous studies have been conducted to evaluate the effect of a treatment with PGF $_{2 \alpha}$ or its analogues within $40 \mathrm{~d}$ of calving on reproductive performance of dairy cows. It is noteworthy that there is a wide disparity between the results
(Burton \& Lean, 1995). Young et al. (1984), for instance, reported a significant improvement in the first service conception rates of cows given $\mathrm{PGF}_{2 \alpha}$, whereas a study conducted by Macmillan et al. (1987) and including 1813 cows could not support these findings.

To shed some light on this issue, the overall objective of this study was to evaluate the quality and comparability of published literature and to summarize the effect of $\mathrm{PGF}_{2 \alpha}$ for the treatment of endometritis. Specifically we set out to test two hypotheses: (1) studies published are diverse in respect to relevant quality criteria such as control groups, blinding, randomization, and sample size and (2) the majority of trials reveal an improvement of the reproductive performance through the application of $\mathrm{PGF}_{2 \alpha}$ to cows with endometritis.

\section{Materials and Methods}

A comprehensive literature search was conducted on 4 August 2010 utilizing the search engine Vetseek (http:// www.vetseek.info), databases Pubmed (http://www. pubmed.gov), Medline (http://www.medline.de), and Animal Production (http://www.ovid.com/site/catalog/ DataBase/22.jsp) to identify literature related to the treatment of endometritis with prostaglandin in dairy cattle. The subject headings 'endometritis AND cattle', 'endometritis AND cattle AND prostaglandin' were used to include all articles written in English or German addressing the treatment of bovine endometritis with $\mathrm{PGF}_{2 \alpha}$. In addition, a systematic review of citations in the retrieved papers was carried out. We defined specific exclusion criteria to only include studies that focus on chronic endometritis, i.e. presence of a purulent ( $>50 \%$ pus) uterine discharge detectable in the vagina $21 \mathrm{~d}$ or more post partum (Sheldon et al. 2006). Furthermore, we excluded studies in which the animals received concomitant treatments with medications other than PGF $2 \alpha$. Also, book chapters, case studies, review articles and abstracts were excluded. Furthermore, publications describing aetiological, epidemiological, microbiological or nutritional results, clinical symptoms or diagnostic procedures were rejected. Articles not meeting the inclusion criteria, owing to wrong indexation, and those not obtainable through the internet, bibliographies or inter-lending services were excluded as well. If multiple publications were retrieved describing the same trial, those containing the least information were regarded as doublets and excluded. Retrieval and management of references was performed with Endnote (Version X3 for Windows, Thomson Reuters, New York, NY, USA).

The remaining publications were evaluated according to various evidence parameters utilizing an evaluation form developed by Arlt (2010) and recently validated by Simoneit et al. (2011). Relevant criteria of the study design such as sample size, the involvement of control groups, either untreated, placebo-treated or treated with a drug other than $\mathrm{PGF}_{2 \alpha}$, blinding and randomization were considered. Furthermore, type and definition of endometritis, diagnostic methods, the drug and dosage applied, route of application, 
Table 3. Relevant criteria of 68 trials studying the efficacy of $\mathrm{PGF}_{2 \alpha}$ treatment of chronically endometritic cows

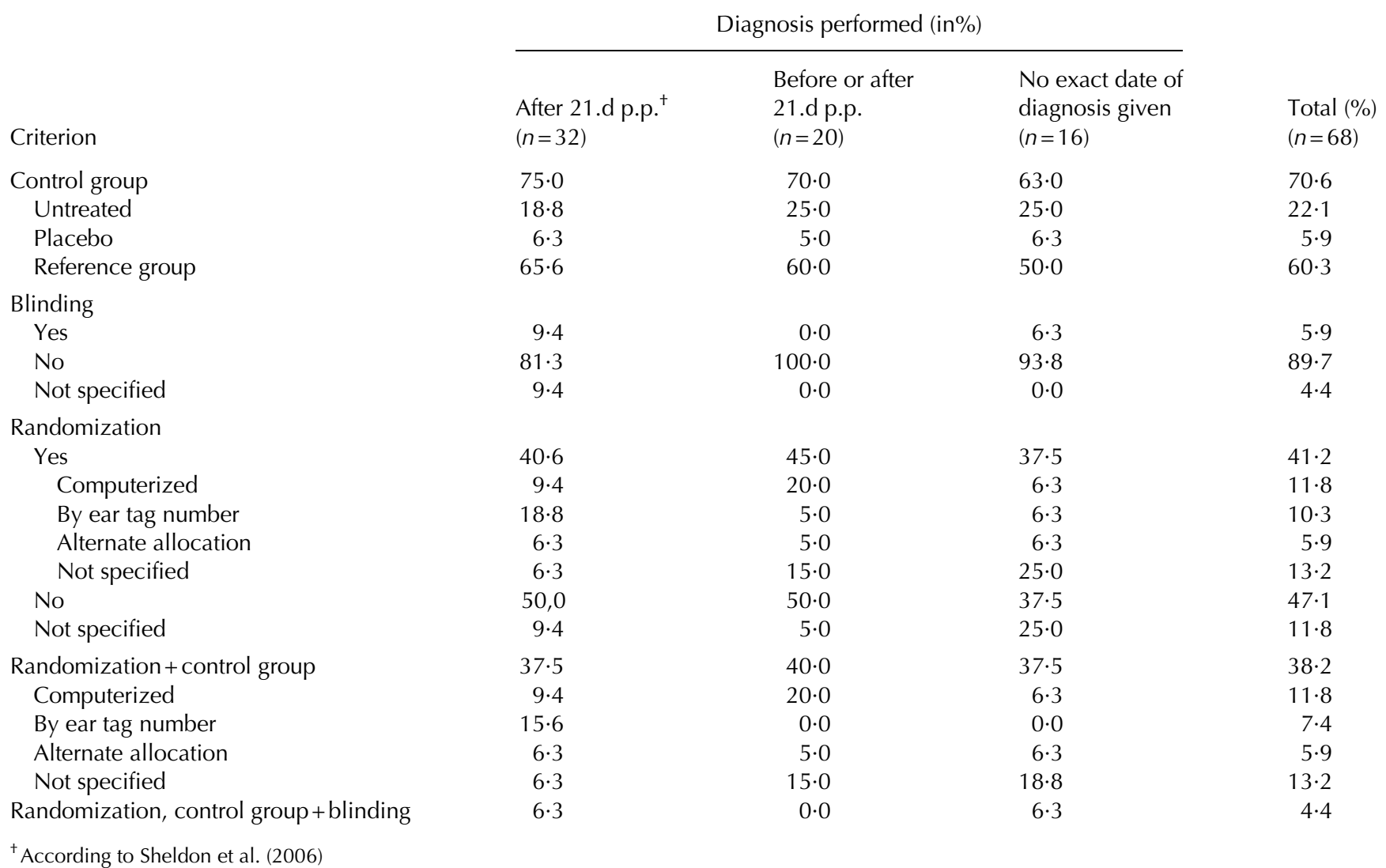

number of treatments, treatment time relative to calving, and reproductive performance parameters, i.e. calving to first service interval, calving to conception interval and conception rate, were documented in a spreadsheet. Descriptive statistics were compiled using SPSS for Windows (Version 18.0; SPSS Inc., Munich, Germany).

\section{Results}

In total, 4393 publications were retrieved (Vetseek, 2369; Pubmed, 570; Medline, 565; Animal Production, 889). After excluding doublets $(n=1670), 2723$ publications remained. According to the exclusion criteria, 2662 indexed articles had to be excluded resulting in 61 remaining publications which comprised 63 individual trials. Because 4 articles were retrieved through search by hand, a total of 65 publications, comprising 68 trials, met the inclusion criteria and were suitable for further analysis (Table 1).

According to Sheldon's (2006) definition of chronic endometritis, diagnosis had to be conducted later than $20 \mathrm{~d}$ post partum. However, several studies complied only partly with this time period $(n=20)$, whereas others did not provide an exact time of diagnosis at all $(n=16)$. To account for this variation, we decided to subdivide the studies according to their date of diagnosis.
More than half of all 68 trials $(51 \cdot 5 \%)$ were older than 20 years (Table 2 ). Trials that did not give a specific definition of endometritis made up $23.5 \%$ of all trials analysed. We found a sample size smaller than 50 in $16 \cdot 2 \%$ of all trials and about one-third of the studies $(36 \cdot 8 \%)$ had included more than 200 animals. Overall, $70 \cdot 6 \%$ of all trials included a control group (Table 3 ). Of those, $60.3 \%$ had a positive (a drug other than $\mathrm{PGF}_{2 \alpha}$ ), 22.1\% an untreated, and $5.9 \%$ a placebo-treated control group. In $41 \cdot 2 \%$ of all trials, the authors stated that allocation to treatment and control group had been conducted in a random manner. In $11.8 \%$ of all studies randomization was computerized, whereas $16 \cdot 2 \%$ allocated the cows enrolled in an alternating order or with the help of ear-tag numbers, and $13 \cdot 2 \%$ did not offer any details concerning the mode of randomization. Our investigation revealed that $38 \cdot 2 \%$ of all trials were controlled and randomized. In this context, control groups were either untreated, placebo-treated or treated with a drug other than $\mathrm{PGF}_{2 \alpha}$. Trials were considered as randomized if the animals had reportedly been allocated to the various groups in random manner, i.e. by chance. Only 3 of those articles (4.4\%) were also blinded.

Among the 68 trials, a wide variety of methods to diagnose the disease in question could be identified (Table 4). However, $13 \cdot 2 \%$ did not specify the particular method used. 
Table 4. Relevant diagnostic and therapeutic criteria of 68 trials studying the efficacy of $\mathrm{PGF}_{2 \alpha}$ treatment of chronically endometritic cows

\begin{tabular}{|c|c|c|c|c|}
\hline \multirow[b]{2}{*}{ Criterion } & \multicolumn{3}{|c|}{ Diagnosis performed (in\%) } & \multirow[b]{2}{*}{$\begin{array}{l}\text { Total }(\%) \\
(n=68)\end{array}$} \\
\hline & $\begin{array}{l}\text { After } 21 \text { d p.p. } \\
(n=32)\end{array}$ & $\begin{array}{l}\text { Before or after } 21 \\
\text { d p.p. } \\
(n=20)\end{array}$ & $\begin{array}{l}\text { No exact date of } \\
\text { diagnosis given } \\
(n=16)\end{array}$ & \\
\hline \multicolumn{5}{|l|}{ Diagnostic methods } \\
\hline External inspection ${ }^{\ddagger}$ & $3 \cdot 1$ & $5 \cdot 0$ & $0 \cdot 0$ & $2 \cdot 9$ \\
\hline Rectal palpation & $34 \cdot 4$ & $0 \cdot 0$ & $0 \cdot 0$ & $16 \cdot 2$ \\
\hline Vaginoscopy & $3 \cdot 1$ & $0 \cdot 0$ & $0 \cdot 0$ & $1 \cdot 5$ \\
\hline External inspection ${ }^{\ddagger}+$ rectal Palpation & $21 \cdot 9$ & $30 \cdot 0$ & $12 \cdot 5$ & $22 \cdot 1$ \\
\hline Rectal palpation + vaginoscopy & $21 \cdot 9$ & $30 \cdot 0$ & $12 \cdot 5$ & $22 \cdot 1$ \\
\hline $\begin{array}{l}\text { External inspection }{ }^{\ddagger} \text {, rectal } \\
\text { palpation + vaginoscopy }\end{array}$ & $6 \cdot 3$ & $20 \cdot 0$ & $6 \cdot 3$ & $10 \cdot 3$ \\
\hline Other & $0 \cdot 0$ & $0 \cdot 0$ & $12 \cdot 5$ & $2 \cdot 9$ \\
\hline Imprecise information & $3 \cdot 1$ & $10 \cdot 0$ & $18 \cdot 8$ & $8 \cdot 8$ \\
\hline Not specified & $6 \cdot 3$ & $5 \cdot 9$ & $5 \cdot 0$ & $13 \cdot 2$ \\
\hline \multicolumn{5}{|l|}{ Multiple treatment(s) } \\
\hline Yes & $34 \cdot 4$ & $10 \cdot 0$ & $6 \cdot 3$ & $20 \cdot 6$ \\
\hline No & $15 \cdot 6$ & $30 \cdot 0$ & $37 \cdot 5$ & $25 \cdot 0$ \\
\hline If necessary/partly & $34 \cdot 4$ & $35 \cdot 0$ & $12 \cdot 5$ & $29 \cdot 4$ \\
\hline Not specified & $18 \cdot 8$ & $25 \cdot 0$ & $37 \cdot 5$ & $25 \cdot 0$ \\
\hline \multicolumn{5}{|l|}{ Route of administration } \\
\hline Intramuscular & $59 \cdot 4$ & $75 \cdot 0$ & $62 \cdot 5$ & $64 \cdot 7$ \\
\hline Subcutaneous & $3 \cdot 1$ & $0 \cdot 0$ & $0 \cdot 0$ & $1 \cdot 5$ \\
\hline Diverse routes used & $9 \cdot 4$ & $5 \cdot 0$ & $37 \cdot 5$ & $5 \cdot 9$ \\
\hline Not specified & $18 \cdot 8$ & $28 \cdot 1$ & $20 \cdot 0$ & $27 \cdot 9$ \\
\hline $\begin{array}{l}\text { Definition of reproductive performance } \\
\text { parameters given }\end{array}$ & $25 \cdot 0$ & $25 \cdot 0$ & $0 \cdot 0$ & $19 \cdot 1$ \\
\hline
\end{tabular}

Table 5. Reproductive performance parameters described in 68 trials studying the efficacy of $\mathrm{PGF}_{2 \alpha}$ treatment of chronically endometritic cows

\begin{tabular}{|c|c|c|c|}
\hline & & ults describec & \\
\hline Criterion & $\begin{array}{l}\text { As } \\
\text { improved }^{+}\end{array}$ & $\begin{array}{l}\text { As } \\
\text { significantly } \\
\text { improved } \\
(P<0 \cdot 05)\end{array}$ & $\begin{array}{l}\text { As not } \\
\text { improved }\end{array}$ \\
\hline $\begin{array}{l}\text { Calving to first service } \\
\text { interval }(n=22)\end{array}$ & $36 \cdot 4$ & $22 \cdot 7$ & $4 \cdot 5$ \\
\hline $\begin{array}{l}\text { Calving to conception } \\
\text { interval }(n=30)\end{array}$ & $50 \cdot 0$ & $23 \cdot 3$ & $20 \cdot 0$ \\
\hline Conception rate $(n=48)$ & $35 \cdot 4$ & $12 \cdot 5$ & $8 \cdot 3$ \\
\hline
\end{tabular}

Concerning reproductive performance parameters, $19 \cdot 1 \%$ of the studies provided a concise definition. By taking a closer look at the single parameters, it becomes obvious that the conclusions of the authors concerning an improvement are only partly proved as statistically significant (Table 5).

Similar observations were made when assessing reproductive performance parameters examined in randomized and controlled trials as well as randomized, controlled, and blinded trials (Table 6).

Considering high-level evidence studies for which a conception rate was calculated $(n=16), 7,7$ and 2 articles respectively revealed a positive, none or a negative effect (Table 7). Of those 7 articles revealing a positive effect, only 3 showed statistical significance. Twenty-two of thirty articles which were attributed to a moderate or high evidence level did not demonstrate a statistically significant effect of a $\mathrm{PGF}_{2 \alpha}$ treatment. Six low-quality papers concluded a positive effect without statistical validation.

\section{Discussion}

The checklists introduced may also be useful for critical appraisal of published reviews, but they are not explicitly designed as quality assessment instruments to determine the quality of articles (Simoneit et al. 2011). Hence, for our study, we applied the evaluation form designed by Arlt et al. (2010).

One might question whether studies older than 20 years should be included in such systematic literature assessment since the dairy industry has changed considerably 
Table 6. Reproductive performance parameters described in 68 trials studying the efficacy of $\mathrm{PGF}_{2 \alpha}$ treatment of chronically endometritic cows

\begin{tabular}{|c|c|c|}
\hline $\begin{array}{l}\text { Reproductive } \\
\text { performance } \\
\text { parameter }\end{array}$ & $\begin{array}{l}\text { Randomized, } \\
\text { controlled trials } \\
(\%)(n=25)\end{array}$ & $\begin{array}{l}\text { Randomized, } \\
\text { controlled, } \\
\text { blinded trials } \\
(\%)(n=3)\end{array}$ \\
\hline $\begin{array}{l}\text { Calving to first service interval } \\
\text { Increase } \\
\text { Statistically significant } \\
\text { Decrease } \\
\text { Statistically significant }\end{array}$ & $\begin{array}{r}40 \cdot 0 \\
8 \cdot 0 \\
0 \cdot 0 \\
16 \cdot 0 \\
8 \cdot 0\end{array}$ & $\begin{array}{r}33 \cdot 3 \\
33 \cdot 3 \\
0 \cdot 0 \\
0 \cdot 0 \\
0 \cdot 0\end{array}$ \\
\hline $\begin{array}{l}\text { Calving to conception interval } \\
\text { Increase } \\
\text { Statistically significant } \\
\text { Decrease } \\
\text { Statistically significant }\end{array}$ & $\begin{array}{r}52 \cdot 0 \\
4 \cdot 0 \\
0 \cdot 0 \\
24 \cdot 0 \\
12 \cdot 0\end{array}$ & $\begin{array}{r}33 \cdot 3 \\
0 \cdot 0 \\
0 \cdot 0 \\
33 \cdot 3 \\
0 \cdot 0\end{array}$ \\
\hline $\begin{array}{l}\text { Conception rate } \\
\text { Increase } \\
\text { Statistically significant } \\
\text { Decrease } \\
\text { Statistically significant }\end{array}$ & $\begin{array}{r}72 \cdot 0 \\
28 \cdot 0 \\
12 \cdot 0 \\
8 \cdot 0 \\
0 \cdot 0\end{array}$ & $\begin{array}{r}33 \cdot 3 \\
0 \cdot 0 \\
0 \cdot 0 \\
0 \cdot 0 \\
0 \cdot 0\end{array}$ \\
\hline
\end{tabular}

Table 7. Effects on conception rate after $\mathrm{PGF}_{2 \alpha}$ treatment described in trials studying the efficacy of $\mathrm{PGF}_{2 \alpha}$ treatment of chronically endometritic cows

\begin{tabular}{|c|c|c|c|c|}
\hline \multirow[b]{2}{*}{ Effect of $\mathrm{PGF}_{2 \alpha}$ treatment } & \multirow[b]{2}{*}{ Total } & \multicolumn{3}{|c|}{ Level of evidence $^{+}$} \\
\hline & & $\operatorname{Low}^{\ddagger}$ & Moderate ${ }^{\S}$ & High" \\
\hline $\begin{array}{l}\text { Positive, statistically } \\
\text { significant }\end{array}$ & 6 & 0 & 3 & 3 \\
\hline Positive, authors' assessment & 15 & 6 & 5 & 4 \\
\hline None & 9 & 0 & 2 & 7 \\
\hline Negative & 7 & 1 & 4 & 2 \\
\hline Total & 37 & 7 & 14 & 16 \\
\hline
\end{tabular}

particularly in respect to housing, feeding, and management (LeBlanc et al. 2006). In the last two decades milk yield has increased by 39.2\% (1990: $6705 \mathrm{~kg} / \mathrm{cow}$; 2009: $9333 \mathrm{~kg} /$ cow) (Blayney, 2002; USDA, 2010) and 45.2\% (1990: $4857 \mathrm{~kg} / \mathrm{cow}$; 2010: $7050 \mathrm{~kg} / \mathrm{cow}$ ) (BMELV, 1992; ADR, $2010)$ in the United States and Germany, respectively. Thus, it can be questioned whether trials conducted more than 20 years ago support adequate evidence for specific recommendations in livestock health care today. On the other side, these studies provided observational evidence for the efficacy of $\mathrm{PGF}_{2 \alpha}$ and were a relevant component of the development of the current best-practice standard.

The majority of the trials evaluated had insufficient detail of study design. In $16 \cdot 2 \%$ of the trials the total sample size was smaller than 50 , and only $36 \cdot 8 \%$ had included more than 200 animals. More important than the absolute number of animals included, is the question whether the sample size of each group was large enough to test the proposed research hypothesis. None of the authors, however, mentioned a calculation of sample size for the study. Therefore, a final evaluation of the adequacy of the sample size is not possible.

Our investigation revealed that only about one-third of all trials was controlled and randomized. The mean sample size of those trials was $165 \cdot 3 \pm 99$. Untreated or placebo-treated control groups were included in only $28 \%$ of all trials. An overall shortage of randomized, controlled trials in veterinary medicine was also described by Kastelic (2006). This deficiency might be due to the high costs involved and ethical issues related to leaving diseased animals untreated.

A computer-generated random allocation of animals to treatment groups was implemented in only about a fourth of the randomized trials. The other trials allocated their animals according to ear-tag numbers or in an alternating order or did not offer any details concerning the mode of randomization at all.

According to Lund et al. (1994), a truly random allocation scheme (assured by computer or random number table) implies a predetermined probability for every potential study subject for assignment to a treatment group. In contrast, systematic assignments, e.g. based on days of the week, are not recommended because they are vulnerable to manipulation. Allocation to study groups based on ear-tag numbers, however, can be considered as random because those numbers are assigned at birth and thus long before the study and without any fore knowledge of it.

We speculate that the allocation of animals in studies that claimed to be randomized but did not provide any information about the method $(13 \cdot 2 \%)$ should a priori be considered as not randomized but as haphazard. However, missing data, especially regarding older studies, could be due to incomplete reporting. Therefore, studies with missing data should not a priori be judged as low quality.

Randomized, controlled clinical trials provide the highest validity of results obtained (Schulz et al. 1995). However, this specific study design is not applicable to every question (Antes, 1998; Smith \& Pell, 2003). For example, it might be unethical to include an untreated control group if that would inevitably imply serious distress, suffering or even death for the animals involved (Sayre et al. 2010). The process of randomization helps to assure that treatment groups are comparable with respect to known and unknown factors that could influence the primary outcome variable of the study (Lund et al. 1994). Our finding that only $38 \cdot 2 \%$ of the trials were controlled and randomized clearly limits the strength of evidence of $\mathrm{PGF}_{2 \alpha}$ as treatment of bovine endometritis.

Conclusions or treatments inferred from uncontrolled and unrandomized trials are in general less likely to be true than those based on randomized controlled trials. In our analysis, we found a considerable percentage $(25.0 \%)$ of uncontrolled studies that described reproductive performance 
parameters. Drawing inference and implementing treatment decisions based on such results, however, should be considered carefully. A wide variety of diagnostic methods were applied in the 68 trials evaluated. It has been demonstrated that different methods to diagnose endometritis differ in their sensitivity (Drillich et al. 2002; LeBlanc et al. 2002b).

The classification of cytological endometritis and purulent vaginal discharge has been most recently described (Runciman et al. 2008; Dubuc et al. 2010a). Owing to a shortage of studies based on this new classification, we decided to use the definition by Sheldon (2006).

Specific and repeatable exclusion criteria were defined to exclude studies that did not focus on chronic endometritis, i. e. after $21 \mathrm{~d}$ after parturition (Sheldon et al. 2006). Several studies, however, complied only partly with this time period and had also enrolled cows earlier, whereas others did not provide an exact time of diagnosis at all. Therefore we decided to classify studies according to their time of diagnosis. This classification was important because several authors observed a significant self-cure rate in cows with chronic endometritis during the first weeks post partum. The self-cure rate ranged from $92 \%$ in the first week to $25 \%$ in the seventh week post partum (Falkenberg \& Heuwieser, 2005; Hirsbrunner et al. 2006). A considerable inconsistency existed also regarding the calculation of the pregnancy outcome. Some authors assessed overall conception rates, whereas others calculated a first service conception rate or a pregnancy rate. Overall, only $19 \cdot 1 \%$ of all studies provided a concise definition of reproductive performance parameters used. In addition, a specific definition of endometritis was not given in $23.5 \%$ of all trials analysed. This lack of homogeneity to some extend limits comparability of study results.

Our results demonstrate that an impressive percentage of studies addressing the efficacy of $\mathrm{PGF}_{2 \alpha}$ are severely flawed in the study design, and that comparability between publications is limited owing to considerable differences. In human medicine intensive examination of the appraising of available literature has been conducted in the framework of evidence-based medicine (EBM). However, Arlt \& Heuwieser (2010) point out the need for further appraisal of scientific publications in veterinary medicine.

One objective of the study was to summarize the effect of $\mathrm{PGF}_{2 \alpha}$ for the treatment of endometritis. Of those trials assessing reproductive performance parameters (calving to first service interval, calving to conception interval, conception rate), statistically significant effects on reproductive performance were reported only in a small fraction of trials. Twenty-two of 37 studies that evaluated conception rate were attributed to a moderate or high evidence level and did not show any statistically significant effect of PGF $_{2 \alpha}$ treatment (Table 7). A positive effect was revealed by 21 articles. Of those, only 6 reported a statistical significance. However, it is stressed by different authors that different factors, such as the time of diagnosis (LeBlanc et al. 2002b), the severity of endometritis, or the additional occurrence of other puerperal disorders (Burton \& Lean, 1995) may influence the efficacy of a $\mathrm{PGF}_{2 \alpha}$ treatment. Based on our results, we propose a tendency of low-quality papers concluding a positive effect without statistical validation $(n=6)$. However, it is important to emphasize that lowquality trials do not necessarily show larger effects of a certain intervention (Kunz \& Oxman, 1998). We conclude that the evidence for the efficacy of $\mathrm{PGF}_{2 \alpha}$ for the treatment of chronic bovine endometritis is limited. In combination with most recent results (Dubuc et al. 2010b), we suggest that the use of $\mathrm{PGF}_{2 \alpha}$ as a standard treatment for endometritis should be critically reconsidered. Further research in the form of controlled, randomized and blinded trials is required to assess and quantify the efficacy of this treatment.

\section{References}

ADR 2010 Rinderproduktion in der Bundesrepublik Deutschland 2010-Das Wichtigste in Kürze. [Cattle production in Germany 2010.] http://www. adr-web.de/list_statistik.html

Antes G 1998 Evidence-based medicine. Internist 39 899-908

Arlt S, Dicty V \& Heuwieser W 2010 Evidence-based medicine in canine reproduction: quality of current available literature. Reproduction in Domestic Animals 45 1052-1058

Arlt S \& Heuwieser W 2005 Evidence based veterinary medicine. Deutsche Tierärztliche Wochenschrift 112 146-148

Arlt S \& Heuwieser W 2010 Evidence-Based Complementary and Alternative Veterinary Medicine-a contradiction in terms? Berliner und Münchener Tierärztliche Wochenschrift 123 377-384

Arlt S, Padberg W, Drillich M \& Heuwieser W 2009 Efficacy of homeopathic remedies as prophylaxis of bovine endometritis. Journal of Dairy Science 92 4945-4953

Azawi OI 2008 Postpartum uterine infection in cattle. Animal reproduction science 105 187-208

Bassler D \& Antes G 2000 Wie erhalte ich Antworten auf meine Fragen. [How do I receive answers to my questions.] In Book Lehrbuch Evidenzbasierte Medizin in Klinik und Praxis, pp. 432 Köln was published by R Kunz, G Ollenschläger, H Raspe, G Jonitz \& FW Kolkmann.

Blayney DP 2002 The Changing Landscape of U.S. Milk Production. http:// www.ers.usda.gov/Publications/SB978/

BMELV 1992 Statistisches Jahrbuch über Ernährung, Landwirtschaft und Forsten 1992 [Annual book of statistics concerning nutrition, agriculture and forestry]. In Book Statistisches Jahrbuch über Ernährung, Landwirtschaft und Forsten 1992. Bonn: Wirtschftsverlag NW GmbH Bremerhaven

Burton NR \& Lean IJ 1995 Investigation by meta-analysis of the effect of prostaglandin F2 alpha administered post partum on the reproductive performance of dairy cattle. Veterinary Record 136 90-94

Cockcroft P \& Holmes M 2003 Introduction. In Handbook of EvidenceBased Veterinary Medicine, pp. 1-22. Oxford: Blackwell Publishing Ltd, 9600 Garsington Road, Oxford OX4 2DQ, UK.

Drillich M, Bergmann J, Falkenberg U, Kurth A \& Heuwieser W 2002 Effects of the intensity of a post partum examination on reproductive performance in high yielding dairy cows. Deutsche Tierärztliche Wochenschrift 109 386-390

Dubuc J, Duffield TF, Leslie KE, Walton JS \& LeBlanc SJ 2010a Definitions and diagnosis of postpartum endometritis in dairy cows. Journal of Dairy Science 93 5225-5233

Dubuc J, Duffield TF, Leslie KE, Walton JS \& LeBlanc SJ 2010b Risk Factors, Impacts, and Therapy for Endometritis in Dairy Cows. In Proceedings of the 43rd Annual Conference of the American Association of Bovine Practitioners, 233-233

Dubuc J, Duffield TF, Leslie KE, Walton JS \& Leblanc SJ 2011 Randomized clinical trial of antibiotic and prostaglandin treatments for uterine health 
and reproductive performance in dairy cows. Journal of Dairy Science 94 $1325-1338$

Falkenberg U \& Heuwieser W 2005 Influence of time of initiation of a prostaglandin F2alpha protocol in dairy cows with puerperal endometritis. Deutsche Tierärztliche Wochenschrift 112 252-256

Gilbert RO \& Schwark WS 1992 Pharmacologic considerations in the management of peripartum conditions in the cow. Veterinary Clinics of North America: Food Animal Practice 8 29-56

Hirsbrunner G, Burkhardt HW \& Steiner A 2006 Effects of a single administration of prostaglandin F2alpha, or a combination of prostaglandin F2alpha and prostaglandin E2, or placebo on fertility variables in dairy cows $3-5$ weeks post partum, a randomized, double-blind clinical trial. Reproductive Biology and Endocrinology 465

Holmes M \& Cockcroft P 2004 Evidence-based veterinary medicine 1. Why is it important and what skills are needed? In Practice $\mathbf{2 6} 28-33$

Kastelic JP 2006 Critical evaluation of scientific articles and other sources of information: an introduction to evidence-based veterinary medicine. Theriogenology 66 534-542

Kunz R \& Oxman AD 1998 The unpredictability paradox: review of empirical comparisons of randomised and non-randomised clinical trials. British Medical Journal 317 1185-1190

Lean IJ, DeGaris PJ, McNeil DM \& Block E 2006 Hypocalcemia in dairy cows: meta-analysis and dietary cation anion difference theory revisited. Journal of Dairy Science $\mathbf{8 9}$ 669-684

Lean IJ, Rabiee AR, Duffield TF \& Dohoo IR 2009 Invited review: Use of meta-analysis in animal health and reproduction: methods and applications. Journal of Dairy Science 92 3545-65

LeBlanc SJ 2008 Postpartum uterine disease and dairy herd reproductive performance: a review. Veterinary Journal 176 102-114

LeBlanc SJ, Duffield TF, Leslie KE, Bateman KG, Keefe GP, Walton JS \& Johnson WH 2002a Defining and diagnosing postpartum clinical endometritis and its impact on reproductive performance in dairy cows. Journal of Dairy Science $\mathbf{8 5} 2223-2236$

LeBlanc SJ, Duffield TF, Leslie KE, Bateman KG, Keefe GP, Walton JS \& Johnson WH 2002b The effect of treatment of clinical endometritis on reproductive performance in dairy cows. Journal of Dairy Science $\mathbf{8 5}$ 2237-2249

LeBlanc SJ, Lissemore KD, Kelton DF, Duffield TF \& Leslie KE 2006 Major advances in disease prevention in dairy cattle. Journal of Dairy Science 89 1267-1279

Lund EM, James KM \& Neaton JD 1994 Clinical trial design: veterinary perspectives. Journal of Veterinary Internal Medicine 8 317-322

Macmillan KL, Day AM, Taufa VK, Henderson HV \& Allison PA Year Some effects of injecting a prostaglandin F2-alpha (Lutalyse) during the post partum period on the subsequent fertility of dairy cows. In Proceedings of the 47st Annual NZSAP Conference, pp. 65-68
Mair TS \& Cohen ND 2003 A novel approach to epidemiological and evidence-based medicine studies in equine practice. Equine Veterinary Journal 35 339-340

Olson JD 1996 Metritis/endometritis: medically sound treatments. In Proceedings of 29th Annual Conference of the American Association of Bovine Practitioners, San Diego CA, USA, pp. 8-14

Plaizier JC, Lissemore KD, Kelton D \& King G) 1998 Evaluation of overall reproductive performance of dairy herds. Journal of Dairy Science $\mathbf{8 1}$ 1848-1854

Rabiee AR, Lean IJ \& Stevenson MA 2005 Efficacy of Ovsynch program on reproductive performance in dairy cattle: a meta-analysis. Journal of Dairy Science 88 2754-2770

Runciman DJ, Anderson GA, Malmo J \& Davis GM 2008 Use of postpartum vaginoscopic (visual vaginal) examination of dairy cows for the diagnosis of endometritis and the association of endrometritis with reduced reproductive performance. Australian Veterinary Journal 86 205-213

Sackett DL, Rosenberg WM, Gray JA, Haynes RB \& Richardson WS 1996 Evidence based medicine: what it is and what it isn't. British Medical Journal 312 71-72

Sayre MR, O'Connor RE, Atkins DL, Billi JE, Callaway CW, Shuster M, Eigel B, Montgomery WH, Hickey RW, Jacobs I, Nadkarni VM, Morley PT, Semenko TI \& Hazinski MF 2010 Part 2: Evidence evaluation and management of potential or perceived conflicts of interest 2010 American Heart Association Guidelines for Cardiopulmonary Resuscitation and Emergency Cardiovascular Care. Circulation 122 S657-S664

Schulz KF, Chalmers I, Hayes RJ \& Altman DG 1995 Empirical evidence of bias. Dimensions of methodological quality associated with estimates of treatment effects in controlled trials. Journal of the American Medical Association 273 408-412

Sheldon IM 2009 Defining postpartum uterine disease and the mechanisms of infection and immunity in the female reproductive tract in cattle. Biology of Reproduction 81 1025-1032

Sheldon IM, Lewis GS, LeBlanc S \& Gilbert RO 2006 Defining postpartum uterine disease in cattle. Theriogenology 65 1516-1530

Simoneit C, Heuwieser W \& Arlt S 2011 Evidence-based medicine in bovine, equine and canine reproduction: quality of current literature. Theriogenology 76 1042-1050

Smith GC \& Pell JP 2003 Parachute use to prevent death and major trauma related to gravitational challenge: systematic review of randomised controlled trials. British Medical Journal 327 1459-1461

USDA 2010 Milk Production. http://usda01.library.cornell.edu/usda/nass/ MilkProd//2010s/2010/MilkProd-12-17-2010.txt

Young IM, Anderson DB \& Plenderleith RW 1984 Increased conception rate in dairy cows after early post partum administration of prostaglandin F2 alpha THAM. Veterinary Record 115 429-431 